\title{
Fish for grain? Archaeoentomological research and emerging patterns of exchange
}

\author{
EVA PANAGIOTAKOPULU
}

\begin{abstract}
Panagiotakopulu, E. 2019. Fish for grain? Archaeoentomological research and emerging patterns of exchange. AmS-Skrifter 27, 93-105, Stavanger. ISSN 0800-0816, ISBN 978-82-7760-183-0.

A novel pathway for understanding exchange is via what might be termed historical autecology, in particular, trying to assess introductions and invasive insect species in the environments under investigation. Invertebrates can provide very detailed information on this front, as they inevitably accompany any trading or raiding activities, in ships, either in ballast, dunnage or goods, and overland in packing or commodity. Grain was widely shipped to the north from southern Baltic and North Sea ports, and archaeoentomological research in northern Norway and Iceland has demonstrated that exotic pests for these parts of the world, which rely on the warmth of the storerooms for their survival, arrived as part of the exchange process of fish or skins for grain; a range of other species were transported in dunnage and ballast. This paper discusses insect results and mechanisms for insect pest introductions from a range of sites relevant to the Hanseatic trade, including North Atlantic ones, to show the potential of this research and to provide a framework for future research.
\end{abstract}

Eva Panagiotakopulu, School of GeoSciences, University of Edinburgh, Drummond Street, EDINBURGH EH8 9XP, UNITED KINGDOM. E-mail: Eva.P@ed.ac.uk

Keywords: fossil insects, cereals, stockfish trade, North Atlantic, ports, shipwrecks

\section{'Our bread indeed is but indifferent, occasioned by the quantity of Vermin that are in it."}

\section{Introduction}

Understanding the details behind the Hanseatic trade has to be a multidisciplinary affair, where all aspects of the topic are studied in detail, traded commodities included $^{2}$. From coastal fisheries to urban centres, the Hanse created a trade network characterized by a varied degree of reliance on exchange of commodities. The study of relevant environments, in both trading centres and their hinterland, often centres around perishable materials and in several cases the only way to reconstruct these is by studying proxy material which is preserved in the archaeological record.

The use of insect remains in the interpretation of archaeological environments in relation to trade has concentrated on faunas associated with immediate human environments, ectoparasites and pests of stored products. ${ }^{3}$ In particular, early movement of the so-called human flea, Pulex irritans L., in relation to exchange of commodities provided an understanding of the significance of relevant research in terms of biogeography. ${ }^{4}$

Ships, harbours, cargoes and other materials from ports are a significant part of archaeological research but often there is little concentration on the organic materials and even less on insects. Often this has to do with lack of preservation and suitable deposits, as well as lack of knowledge of the potential of the technique or low prioritization in terms of funded research. Currently, there has been no systematic research which encompasses insect studies associated with known Hanse sites (although see relevant publications on Novgorod). ${ }^{5}$ The information, where available, tends to be slight and scattered, but it still provides a strong indicat ion of the results which potentially lie ahead. This paper looks into the Hanseatic trade from an insect point of view and aims to summarize 
relevant insect research, including studies from the North Atlantic, to show the potential of this research and to provide a framework for future work.

\section{The period before the Hanse - insect research from Viking sites}

Although there is limited archaeoentomological research which focusses on the Hanseatic ports per se, research on insect remains from the Viking North Atlantic showcases the use of the technique for tracking the trade of commodities and biological invasions. Insect research which covers the Norse colonization in the North Atlantic islands, from initial settlement (Icel. landnám) onwards, gives a good example of what relevant research could achieve. One of the most interesting aspects of the Norse colonization is the fact that landscapes previously untouched by humans, as for example in the case of Iceland, or hardly modified by human impact, were severely altered after the Norse arrived in the area. ${ }^{6}$ Introduced species on these landscapes ranged from large mammals to invertebrates, some minute irritants, which were numerous and formed significant indoor assemblages, context specific to the synanthropic environments of the farms and often linked with fodder, haymaking and domestic animals. ${ }^{7}$ Part of the introduced fauna was dependent on the warmth of farms to survive, and as a result dependent on the colonizers, to the extent that in Greenland, when the Norse disappeared from the landscape, the introduced faunas vanished with them. ${ }^{8}$ Several of the species introduced, for example the hay fauna (e.g. the beetles Xylodromus concinnus [Marsham], Latridius minutus/pseudominutus [L.]/[Strand], Quedius mesomelinus [Marsham] and Omalium excavatum Steph.) most probably arrived in dunnage and ballast, ${ }^{9}$ a source examined in terms of later trans-Atlantic trade by Carl Lindroth. ${ }^{10}$ The not-so-frequent imports of cereals were accompanied with imports of more exotic pests, the grain weevil, Sitophilus granarius L. and the saw-toothed grain beetle, Oryzaephilus surinamensis L. ${ }^{11}$

From a theoretical point of view, looking at North Atlantic island faunas, type of vessel, the length and the frequency of the journeys, the volume of commodities on the vessel and also the number of people (and animals) during the journey must have had implications for the successful introduction of new species. The more remote environments of south-west Greenland involve less species introduced by the Norse than Iceland and the Faroe islands; Aphodius lapponum
Gyll., for example, does not make it to Greenland, ${ }^{12}$ perhaps a biogeographic accident in terms of what arrived alive or found immediate suitable habitats on the long journey on the Viking shipping vessels.

Beginning in the tenth and extending to the thirteenth century larger cargo ships made their appearance in the North Atlantic. ${ }^{13}$ These carried larger cargoes, more ballast and more effectively utilized sail, and over a few hundred years they became specialized trading vessels, while more slender, lighter vessels were dedicated to warfare. ${ }^{14}$ The larger cargo ships did not need to be beached and the nature and location of harbours changed as a consequence. The hulls were also ideal environments for hosting uninvited guests, such as rodents and insects and any insects brought in on ballast, dunnage and cargo or attached to humans and animals, could become part of the shipboard community or be offloaded as part of the host harbour insect assemblage.

\section{The archaeoentomological approach}

To obtain an understanding of the movement of commodities, often perishables, and resultant biological invasions along the Hanse routes, systematic sampling from all probable contexts, where there is relevant preservation, waterlogging and/or anaerobic conditions, is needed. Five-litre samples, or smaller where the volume is not available, from archaeological contexts are key to retrieval of insect remains. Sampling of contexts both from domestic and public areas from relevant Hanse and other ports would provide the possibility to map the presence of invertebrates and understand distributions and how invasive species became established. Material from immediately offshore sediments around ports, as for example, that from the Viking Age entrepot at Birka on Lake Mälaren, Sweden, may also repay investigation..$^{15}$ Sampling from shipwrecks, including bilges, cargo holds and cabins or other areas with stored materials across the hull of boats and between planks, is also needed to obtain an understanding of the pathways for introduced species. ${ }^{16}$ Sample processing for insect remains follows the method devised by Coope and Osborne. ${ }^{17}$ Extraction of insect fossil remains is achieved by carefully disaggregating each sample in warm water over a $300 \mu \mathrm{m}$ sieve to remove silt. The residue is then left to drain, mixed with paraffin (kerosene), and cold water added to allow the insect remains to float. The float is retained on a $300 \mu \mathrm{m}$ sieve and washed with detergent to eliminate 
traces of paraffin. The process is repeated three times. The residue is stored in ethanol and then sorted under a low-power stereomicroscope. The insect remains are identified using a modern comparative collection and relevant identification keys. All specimens are identified to the lowest taxonomic level possible, preferably to species level. The results are expressed as minimum number of individuals (MNI) in taxonomic order in spreadsheet form. $^{18}$

\section{Shipwrecks and their importance}

Shipwrecks provide the chance to examine a rarity in archaeology, a unique moment in time and to refine details about a particular event, ${ }^{19}$ and occasionally commodities which might not otherwise be visible. Although there has been limited research on organic remains from shipwrecks, and even less so on insect remains, these studies are important as they complete the picture painted by historical sources, adding the details which tend to be omitted. Major Hanse traded materials ranged from stockfish and cloth to grain and flour in the North Atlantic and tar, furs and skins in the Baltic. ${ }^{20}$ Most of the commodities traded were, without exception, accompanied by insects, accidental travellers, occasionally pests, which were able to hitch a ride as far as the most remote locations.

The movement of pests of cereals as a result of the North Atlantic stockfish trade ${ }^{21}$ shows how the accidental introduction of synanthropic species and anthropochores found few barriers in their dispersal. Apart from within traded commodities, invertebrates were able to exploit additional pathways. Dunnage, e.g. wood, woodchips, hay, grass and other packing materials, was used to pack and secure goods on ships to avoid any damage to the vessel's hull. ${ }^{22}$ A classic example of use of dunnage from archaeology comes from the Late Bronze Age boat of Uluburun, wrecked off the coast of present day Turkey, where there is evidence for one of the earliest uses of brushwood as packing material. ${ }^{23}$ Ballast, which in some cases consisted of saleable materials, was used to keep the vessel afloat, and provided another means of movement of biota. ${ }^{24}$ In terms of material, such as stone, being transported en masse a long way from their original source, this is clearly seen at several medieval ports. The king's antiquary, John Leland provides a contemporary, sixteenth-century account which links the Icelandic stockfish trade with ballast stones used to construct the cobbled streets in Hull, East Yorkshire, ${ }^{25}$ and the presence of Scandinavian and Icelandic rocks has been linked with ballast for the Hanseatic trade in Kings Lynn. ${ }^{26}$ Sometimes, as in the nineteenth-century instance described by Leslie, ${ }^{27}$ a little farming may have taken place on ballast:

'In ships bound upon long voyages in ballast, such as those engaged in the North American timber trade, it was not unusual for the captain to do a little practical farming in the hold of his ship by planting out upon the freshly trimmed ballast, cabbage, lettuce, spring onions, or any edible root that was likely to thrive in the soil he chanced to carry across the Atlantic with him. Most ships, some years back, had a small kitchengarden planted in boxes of earth in the jolly-boat, which boat was further crammed to her gunwales with greengroceries of every sort.'

Animals have been part of the commodities traded or in some cases companions of sailors during the journeys and the vessels were in effect microcosms not that dissimilar to the environments in and around harbours of the relevant ports.

\section{Insect remains from shipwrecks}

From the Baltic Sea to Iceland, the Hanse was in control of much of the trade in commodities and in theory at least their itineraries would also be a biogeographic route for any species hitching a ride on the boats. There are few studies which examine insect remains from shipwrecks and even fewer which are the result of systematic sampling. The brief overview of insect material recovered from shipwrecks below (Fig. 1), including the single Hanse wreck wherefrom insect faunas have been studied, provides a summary of relevant data. ${ }^{28}$

The Roman shipwreck recovered near the Roman fort at Laurium on the Rhine, beneath the modern town of Woerden, the Netherlands, already provides faunas which are dominated by synanthropic species. ${ }^{29}$ The house spider, Tegenaria domestica (Clerck), and the dipterous field pest Oscinella frit (L.), alongside exotic beetles, primary pests, like Tenebrio molitor L., Alphitobius bifasciatus Say, and Sitophilus granarius and also secondary ones, which exploit already infested cereals, such as Oryzaephilus surinamensis, Palorus ratzeburgi Wiss., and Cryptolestes turcicus (Grouv.), among others, provide an overview of some of the contents of the vessel. Mould beetles Typhaea stercorea L. and sphaerocerid flies, which feed on high protein deposits, and their predators, including Philonthus sp., comprise the rest of the fauna. The picture is that of a cargo which included infested 


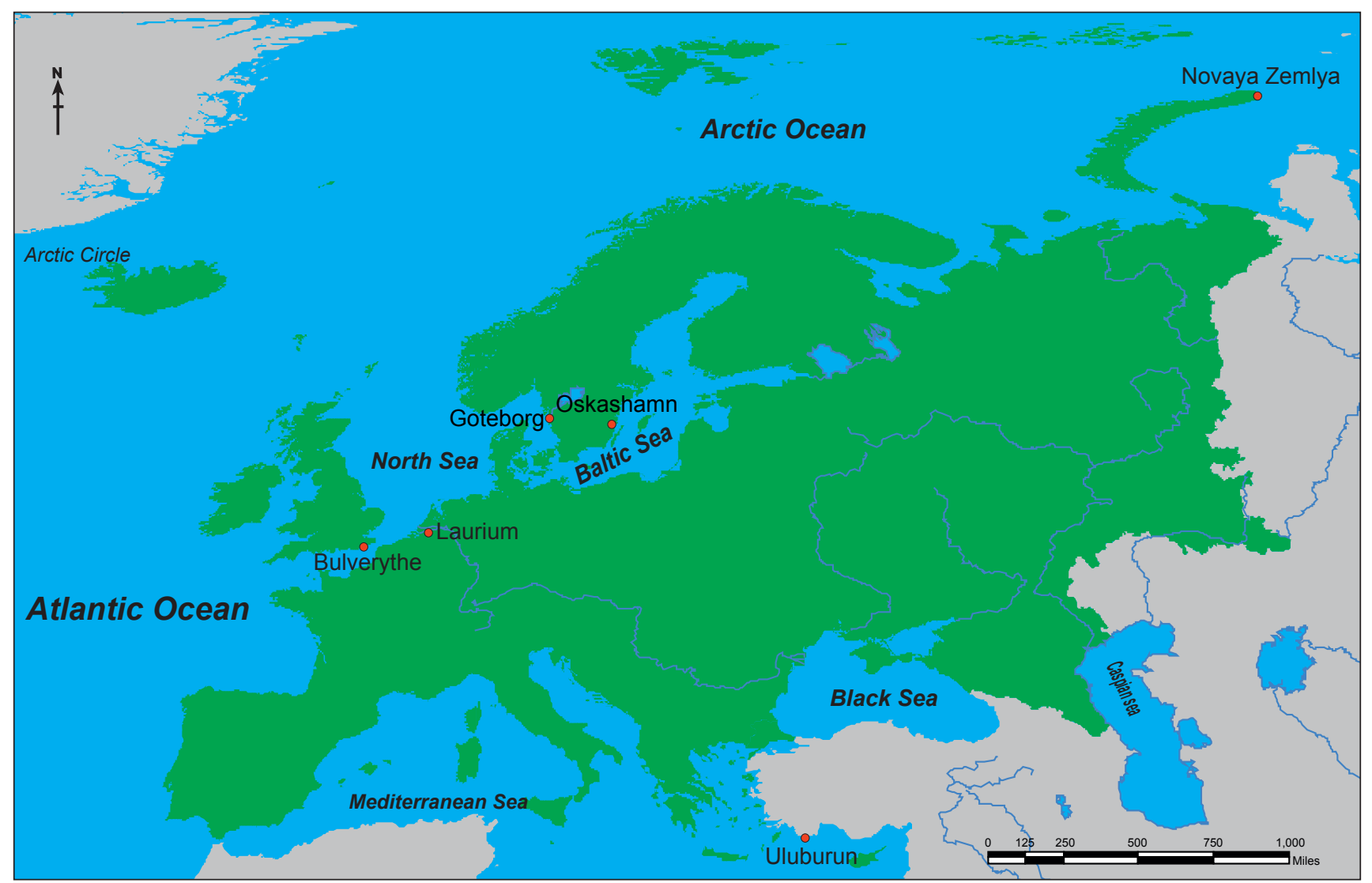

Fig. 1. Location map of shipwrecks mentioned in the text. ${ }^{91}$

cereals whilst the residual ship fauna is typical of what would be expected in hay, which would be used either for dunnage or to feed animals on the vessel. Samples from a thirteenth-century wreck of a cog at Oskarshamn in the Baltic produced interesting data. ${ }^{30}$ Among the species recovered, S. granarius, a flightless pest of cereals with origins in the Fertile Crescent, ${ }^{31}$ testified to the trade or provisioning of grain. Ptinus fur (L.), another pest found in grain, spices and a variety of other commodities ${ }^{32}$ was also recovered from the boat. The mould fauna on the boat includes Latridius gemellatus (Mann.) (=L. nidicola $[\mathrm{Palm}])$, a species associated with woodland but also recovered from straw $^{33}$ and Dienerella filiformis (Gyll.) found in mouldy bread and flour ${ }^{34}$ and in cellars and storerooms. ${ }^{35}$ The last two species must have found ideal conditions in the Hanse ships and other cargo vessels, establishing and maintaining shipboard faunas during the long journeys. In addition to these, the housefly, Musca domestica L., with probable origins in early urban centres around the $\mathrm{Nile}^{36}$ and Fannia canicularis (L.), ${ }^{37}$ both linked with foul conditions and excrements were also recovered from the Oskarshamn wreck. There were no records of $M$. domestica from Norse sites on the North Atlantic islands and the question is whether the accidental distribution of the species as part of trade, had to do partly with the type of vessels used, and the possibility of maintaining populations during the long journeys from Northern Europe across the North Atlantic. ${ }^{38}$ Although there was limited sampling, M. domestica and Fannia sp., together with $S$. granarius, were also recovered from the wreck of the Mary Rose ${ }^{39}$ Henry VIII's flagship which capsized off Portsmouth in 1545. The Mary Rose was a warship and the pests recovered from the vessel are of interest in the context of this discussion, as they probably reflect the level of homogenization of shipboard faunas by the early post-medieval period.

Research from two much later, eighteenth-century East Indiaman wrecks, provides an additional dimension to the biogeography of invasive species. The list of species from the wreck of the Swedish East Indiaman Goteborg ${ }^{40}$ sunk inward bound in 1745 , less than a one kilometre from its home port, included Tenebroides mauritanicus (L.), Cryptolestes ferrugineus (Steph.), Rhyzopertha dominica (F.), Alphitobius diaperinus (Panz.), and Uloma culinaris (L.), species which are all related with food commodities, including grain and flour. The limited faunas of the shipwreck of the Amsterdam at Bulverhythe, East Sussex ${ }^{41}$ included 
Lytta versicatoria (L.), occasionally a pest on olive trees, ${ }^{42}$ but better known for the drug cantharidin and as an additive in what would now be termed quack medicines. ${ }^{43}$ Also note medicinal L. versicatoria in material from the winter huts fashioned out of wood from Willem Barents' ill-fated ship in 1596 on Novaya Zemlya in the Russian Arctic. ${ }^{44}$ Sitophilus oryzae L., a pest perhaps imported from North America ${ }^{45}$ to Europe but probably originally from China ${ }^{46}$ and the Far East, was recorded together with the squarenecked grain beetle, Cathartus quadricollis (GuérinMéneville), of South American origin; introduced to Europe, it thrives on already infested grain. The exotics from these assemblages found on both vessels are a consequence of the development of global markets and explain why these pests are nowadays cosmopolitan.

The movement of Hanseatic and other ships around the North Sea Basin, through the Channel and into the Baltic, offloading and loading ballast, dunnage and cargo at numerous ports, in terms of invertebrates, must have created a residual fauna on the vessels which perpetuated itself with the trade of the same basic commodities. The foul environments onboard must have been ideal for a range of species as they effectively duplicate the conditions they thrive in. ${ }^{47}$
These would form the reservoir for introductions and alongside standardized traded commodities, the Hanseatic trade must have been at least partly instrumental in spreading the same set of invertebrates not only to the main trade centres but also to more remote areas in the North Atlantic region.

\section{Ports, fisheries and traded commodities}

There is little targeted research on insects from major ports, let alone Hanse ports, and samples from sites in the port of Hull have either not been published in full (or cannot be related to the harbour). ${ }^{48}$ The Oslo research has similar limitations, ${ }^{49}$ which largely stem from the late involvement of the palaeoecological specialists rather than the limited work. In theory, invertebrate assemblages from these cosmopolitan areas should be at least in part synanthropic and, together with the natural background faunas ${ }^{50}$, species introduced with ship cargoes including exotics, would form part of these assemblages. Studying a range of contexts from Hanse ports would provide a better understanding of import and redistribution of commodities and the mechanisms involved in the establishment of invasive species. The current data (Fig. 2) provide some

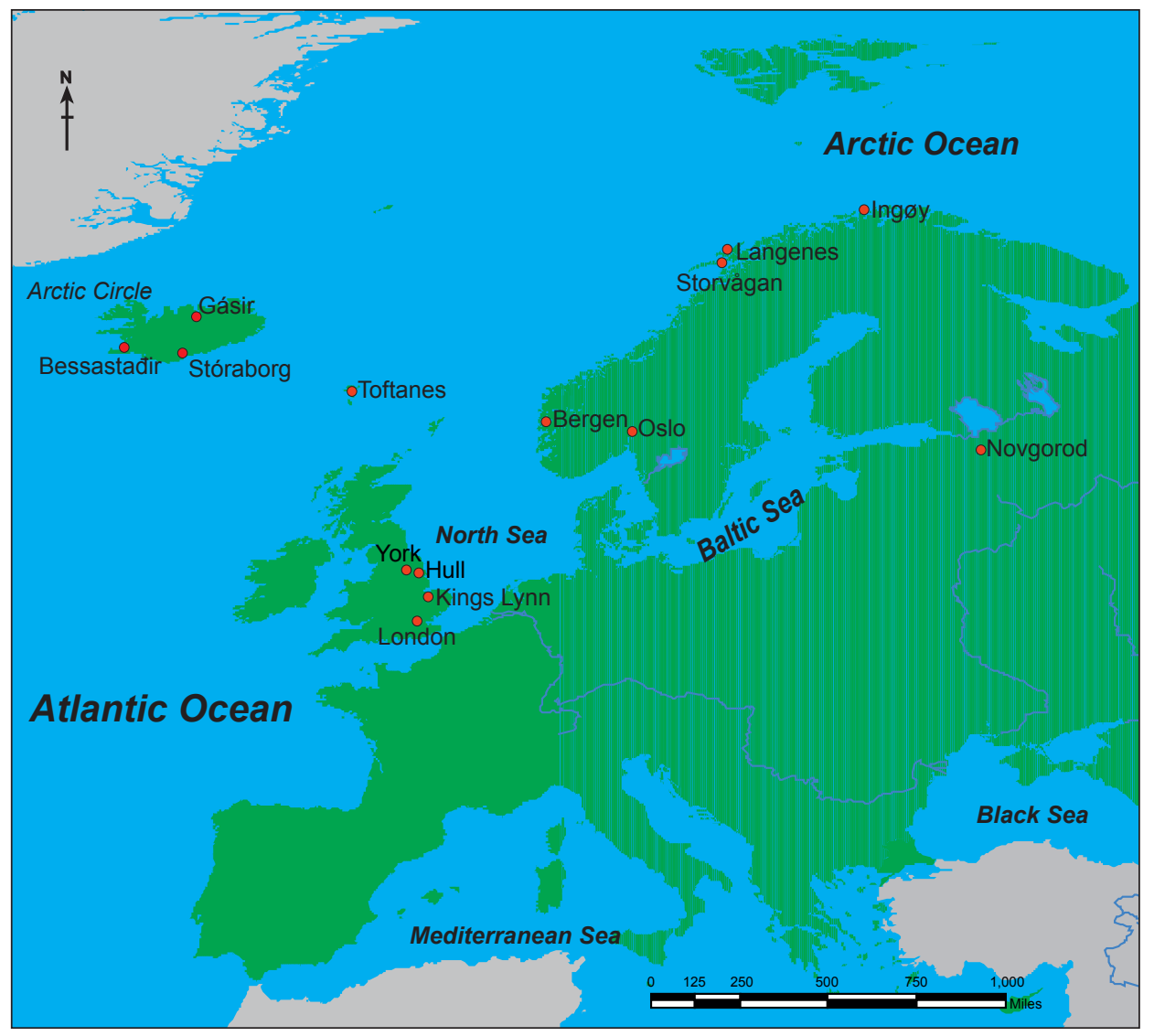

Fig. 2. Location map of relevant sites from the Hanse period mentioned in the text..$^{92}$ 
initial indication about the movement of species on commodities from Northern Europe and the Baltic across the North Atlantic.

\section{The Baltic}

The only insect faunas available from the Baltic littoral, from the Hanse period, come from the flagship site of Novgorod. ${ }^{51}$ Insect assemblages from Troitsky, Novgorod, have been studied by Hellqvist ${ }^{52}$ and Reilly ${ }^{53}$ and they show similar trends in terms of biodiversity, allowing for taphonomic and geographic differences, with other contemporary sites. With much of the timberwork preserved in evident layers of animal dung, ${ }^{54}$ a large part of the insect assemblages is inevitably associated with decaying vegetation and dung. These include several species of Cercyon and Aphodius, Acritus nigricornis (Hoff.) and Platystethus arenarius (Geoff.), while the surrounding environment is represented by species associated with woodland, woodland margins and fen. Another part of the fauna is linked with stored cereals. This includes O. surinamensis, Ptinus fur, and P. villiger Reitter, although the pathway into the deposits is likely to have been through dung. ${ }^{55}$ Sitona lineatus (L.), Bruchus atomarius (L.) and B. loti Payk. are often associated with field infestation of legumes, but may equally have arrived in dung.

Although cereals were produced locally, as for the later city of St Petersburg, ${ }^{56}$ much needed to be imported to sustain the urban centre, and the links with the Hanse led to at least some imports of cereals from the southern Baltic in exchange for other commodities, for example, furs, tar and wax. These could explain some of the pests introduced, although their initial arrival may have been much earlier. More data from a range of sites are needed though to develop any model.

\section{Norway}

Although there is limited fossil insect research from Norway, there are a few studies which provide some information, from medieval Oslo ${ }^{57}$ and the medieval fisheries on the Lofoten islands. ${ }^{58}$ The faunas from Oslo are indicative of the very diverse environments of the medieval city which partly show introductions through trade. Research from Oslo Gamlebyen ${ }^{59}$ and Oslogate 3 and $7^{60}$ provide an understanding of urban faunas and the habitats they represent. The striking characteristic of these assemblages is their diversity as they include faunas associated with dung, fodder, fermented materials, timber and, in the case of Oslo Gamlebyen, cereals. ${ }^{61}$ Species as Quedius mesomelinus (Marsham), Xylodromus concinnus, Ptinius fur, Typhaea stercorea, and Latridius minutus (group), to mention a few, are often connected with human environments, with plant materials, frequently hay, and associated moulds. Platystethus arenarius, Acritus nigricornis and Aphodius species from Oslogate, are associated, among others, with dung of herbivores and indicate sheep, goat and other domestic animals. Some species, including S. granarius, Dienerella sp. and Aglenus brunneus (Gyll.), are probably associated with stored foodstuffs and debris in the houses.

The earliest evidence for pests of stored products in northern Norway comes from the proto-urban site of Storvågan, in the Lofoten islands, where a single specimen of the granary weevil S. granarius was recovered from a sample probably dating from as early as the twelfth century. This is associated with a very diverse pottery assemblage, probably an indication of being part of a network for exchanging fish, perhaps through the main trading centre of Bergen. ${ }^{62}$

Further north, from the remote fisheries station at Langenes on Langøya, in deposits ranging through much of the medieval period, the insects reveal a story of foul assemblages dominated by latridiids, cryptophagids, mycetophagids and species related to storage and decay of hay. ${ }^{63}$

The faunas from the adjacent sites of Vollen and Været include strongly synanthropic elements linked with the semi-permanent settlement and associated activities of the farms, including trade and accidental imports of accompanying exotic pests. Xylodromus concinnus and $X$. depressus (Grav.) and Latridius minutus (L.) (group) are characteristic of these environments. Grain weevils, S. granarius, and sawtoothed grain beetles, O. surinamensis, both pests of stored grain, together with the spider beetle Tipnus unicolor (Pill and Mitt.), which is linked with a range of foul materials including faeces, have been recovered from both sites. The import of cereals in these areas as part of a trading network, which was based on the exchange of fish in exchange for grain, was probably controlled by the Hanseatic port of Bergen, although the pottery from Vågan clearly indicates connections across the North Sea basin to similar ports in England. The same pattern was seen in the fourteenth- to sixteenth-centuries insect assemblages from a midden on the small island of Ingøy, off Hammerfest. ${ }^{64}$ The extent of the exchange of fish probably for cereals 
exemplifies the power of the Hanseatic common market and the way that elite goods were used to draw in even remote, otherwise self-sufficient settlements.

\section{British Isles}

One of the main ports of the Hanse in the British Isles, Hull, has produced diverse assemblages from several sites, including the Magistrate's Court ${ }^{65}$ and Blanket Row. ${ }^{66}$ The assemblages provide evidence for a variety of exotic imports, including figs from Blanket Row. The insects again include various species of cryptophagids and latridiids, which thrive on mouldy plant materials. Although most of them were established in urban environments much earlier during the Roman period. Hall and Kenward have argued for a lack of continuity in urban faunas and their re-establishment as part of the developing trade patterns in the medieval period. ${ }^{67}$ This applies particularly to the grain fauna which would have declined significantly after the collapse of Roman urban centres and which does not appear to have extended beyond the bounds of Empire. The blind and flightless beetle Aglenus brunneus Gyll., thrives in warm decaying mouldy material and has been found in barns and cellars under mouldy hay, straw manure and decaying vegetation. ${ }^{68}$ It has been the subject of extensive discussion by Kenward and more recently by Buckland et al..$^{69}$ and was recovered from sites in Hull, together with a range of other species which specialize in foul rotten material. Dienerella spp., Platystethus arenarius, Acritus nigricornis form part of these foul assemblages, together with a range of ptinid spider beetles, omaliine rove beetles and latridiids. The diversity of the faunas mirrors not only the rural environments around the area,${ }^{70}$ but also the constant import of materials and the introductions of invasive species resulting with these.

The insect assemblages from York, Coffee Yard, ${ }^{71}$ at first glance seem almost like a subset of the Hull faunas in that there is a stronger synanthropic element and a list of similar species, including mould beetles, e.g. Dienerella sp. Corticaria sp. and the pests, S. granarius, O. surinamensis, and Aglenus brunneus. Whether this is taphonomic and linked with the specific contexts or signifies subtle differences between the two sites, is difficult to determine with the limited samples examined.

Equally diverse assemblages from London indicate trade in cereals. ${ }^{72}$ Mouldy hay assemblages, a range of different species, Cercyon haemorrhoidalis (F.), and C. melanocephalus (L.) among them, associated with herbivore dung, Sitona hispidulus (F.), Hypera zoilus (Scop.), Bruchus loti, Bruchus sp. and Bruchidius sp. found in plant materials, perhaps used as fodder, are frequent from such London sites as St John Jerusalem. ${ }^{73}$ Similar faunas were recovered from St. Mary Spital, including ptinids and latridiids such as Dienerella spp., Typhaea stercorea, Latridius minutus (group), and the saw-toothed grain beetle $O$. surinamensis. The cesspit fauna from the Bishop of Winchester's London residence in Southwark shows a similar, if not much more foul assemblage, with the house fly Musca domestica also present in relatively high numbers. ${ }^{74}$

\section{North Atlantic islands}

Although it is difficult to understand fully how trade in the North Atlantic ${ }^{75}$ added to the biodiversity of the North Atlantic islands, there are strong indications for trade of cereals and associated hay faunas from the preHanse period both from the Faroe islands and Iceland. At the one site in the Faroes with extensive insect faunas, Toftanes on Eysturoy, there are no contexts which are contemporary with the Hanse trade but cereal pests have been recovered from an eighteenth-century structure. ${ }^{76}$ Although there is evidence for indigenous cereal cultivation, there is every reason to assume that imports of cereals were continuous since their initial introduction during the settlement period.

In Iceland, where like the Faroes there were no medieval urban centres, insect material from farm sites indicate trade with Europe. A classic example comes from the elite and Danish governor's residence at Bessastaðir, where, in addition to species associated with hay and rotten vegetation material, eleven specimens of $O$. surinamensis and five of S. granarius were recovered. ${ }^{77}$ In view of the fact that there was probably only small scale cereal cultivation in Iceland during the medieval period ${ }^{78}$ both species were probably introduced with imported grain. The Bessastaðir faunas include a long list of synanthropic species and several species of Cercyon indicating that the sampled context, the farm's midden was packed with faecal material and the insect pests were probably digested and excreted with the infested cereals. The scarabaeid beetle Oxyomus sylvestris (Scop.), found in flood debris, compost and decaying vegetation, but not found further north than southern Scandinavia ${ }^{79}$ may have been introduced in ballast.

The farm at Reykholt, where Snorri Sturluson was assassinated in 1241, has been extensively excavated ${ }^{80}$ 


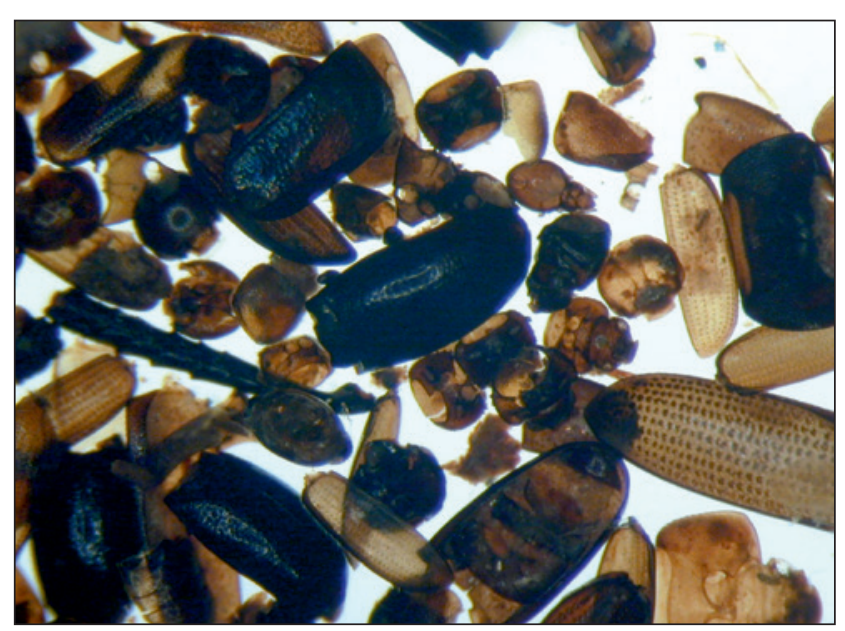

Fig. 3. Insect faunas from medieval Reykholt, Iceland.

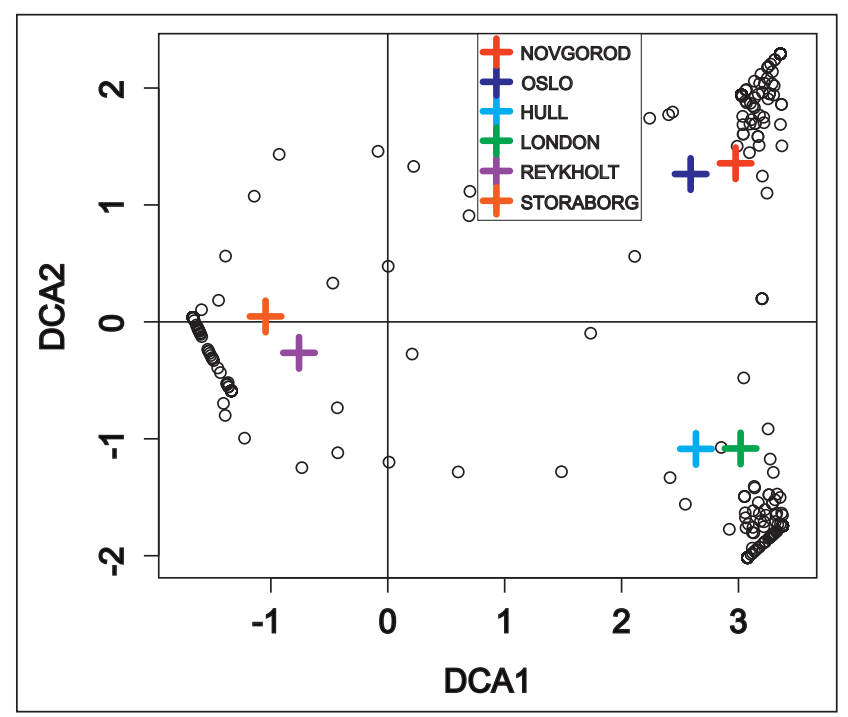

Fig. 4. Detrended Correspondence Analysis (DCA) in the statistical programme $R$ of species lists assemblages from sites potentially involved in the Hanseatic trade. ${ }^{93}$ Species from the different sites are positioned along four DCA axes, and the sites indicated.

and there has been significant associated palaeoecological research. ${ }^{81}$ A sample from underneath the medieval cemetery produced a fauna with large numbers of the blind flightless beetle Aglenus brunneus which must have made it to Iceland in foul cereal residues from Europe, perhaps in malt, fermented barley, for Snorri's beer. ${ }^{82}$ In addition to A. brunneus, the farm's adjacent midden involves a range of synanthropic species and anthropochores (Fig. 3), typically associated with hay storage. ${ }^{83}$

The insect results from the port site of Gásir in Eyjafjörour on the north coast of Iceland reinforce the story of imports of cereals, with the presence of O. surinamensis, Tipnus unicolor and Ptinus sp. from several samples of medieval date. ${ }^{84}$ In view of Iceland's critical position in the medieval stockfish trade ${ }^{85}$ cereals were one of the commodities imported in exchange for fish. Parts of the remaining faunas, including Cryptophagus scanicus L. and Latridius sp., consist of species which frequent hay and decaying vegetation, ${ }^{86}$ and would be as equally at home in the dark rooms of an Icelandic farmhouse as the hull of a Hanseatic boat.

A similar pattern is indicated by the faunas from the late medieval and post-medieval farm at Stóraborg. ${ }^{87}$ Although Stóraborg was a relatively modest farm, the insect remains recovered from its midden and inside are similar to the finds from contemporary elite farms pointing perhaps to a redistribution network and availability of similar goods away from the main ports. The two major grain pests introduced to northern Europe and the North Atlantic islands, S. granarius and $O$. surinamensis, were also present at Stóraborg, together with T. unicolor and a long list of mould beetles and the dung beetle Aphodius lapponum. An individual of its congener A. fimetarius (L.), which has failed to establish populations in Iceland, was also found.

\section{From the Baltic to the North Atlantic}

Although more research from relevant contexts is needed prior to obtaining any meaningful results, an attempt to compare several assemblages from sites potentially involved in the Hanseatic trade from the Baltic to the North Atlantic produced significant results. ${ }^{88}$ The species lists from these sites have been compared using Detrended Correspondence Analysis (DCA) in the statistical programme $\mathrm{R}$ in order to obtain a visual representation of similarities (Fig. 4). ${ }^{89}$ DCA arranges the sites in geometric space and produces a scatterplot where the points close together correspond to sites which include a similar range of species and points far apart correspond to sites which are dissimilar regarding their species composition. ${ }^{90}$

Admittedly taphonomy and different contexts make any comparison problematic, and the task was undertaken with an appreciation of these limitations. The results indicate similarities between the two British sites, Hull and York, essentially on the same navigable river. The two Icelandic sites, Reykholt and Stóraborg also show a degree of similarity regarding their faunas. Interestingly Oslo and Novgorod also have similarities in terms of faunal composition. Part of this pattern is perhaps due to the geographic location and background faunas and the level of urbanization of sites. 
However, the pattern of similarity between Oslo and Novgorod could also be a result of the essentially unity of Baltic and North Sea trade and trade routes which incidentally also shaped part of the insect assemblages. The same does not happen for example in the case of the Icelandic sites where introductions would have been more stochastic and opportunistic. More research is needed to support the argument, and to see whether the insect faunas provide any information for the effects of the initiation of a common market to the biogeography of the insect faunas.

\section{Conclusions}

The Hanseatic trade provides a unique opportunity, to utilize historical texts and archaeological finds in order to understand biogeographic implications of the movement of commodities, ballast, dunnage, people and insects during the late medieval period. The Hanse initiated an era of monopolies and homogenized trade which extended to the North Atlantic islands, with all the consequences involved. Whether these were innovation, access to goods and financial gains or mouldy corn, foul residues, undesired introductions and disease, there is a wealth of information which waits to be uncovered. Looking at the Hanseatic influences in areas of the North Atlantic from the unique ecological trail of the introduced insect fauna looks very promising indeed.

\section{Endnotes}

${ }^{1}$ Joseph Banks, September 1769, in Hooker 2011, 181.

2 Ewert and Salzer 2006; Wubs-Mrozewicz and Jenks 2013; Martin 1986; Pedersen 2006; Schildhauer 1985.

${ }^{3}$ Buckland et al. 2004; Hall and Kenward 2004; Barrett et al. 2007.

${ }^{4}$ Buckland 1991; Buckland and Sadler 1989; Buckland and Sadler 1990; Buckland and Panagiotakopulu 2008; Buckland and Panagiotakopulu 2010; Bain and King 2011.

${ }^{5}$ Hellqvist 1999; Reilly 2012.

${ }^{6}$ Schofield et al. 2013; Panagiotakopulu 2014.

${ }^{7}$ Amorosi et al. 1998; Vickers et al. 2005.

${ }^{8}$ Panagiotakopulu and Buckland 2013.

9 Sadler 1991; Sadler 1999; Buckland and Sadler 1990.

${ }^{10}$ Lindroth 1957.

${ }^{11}$ Panagiotakopulu 2014.

${ }^{12}$ Ibid.

${ }^{13}$ Englert 2015.

${ }^{14}$ Ibid.

${ }^{15}$ Mosley 2009.

${ }^{16}$ Lemdahl et al. 1995.

${ }^{17}$ Coope and Osborne 1968.

${ }^{18}$ Buckland and Buckland 2006.
${ }^{19}$ Deforce et al. 2014; Lorentzen et al. 2014.

${ }^{20}$ Martin 1986; Pedersen 2006; Alsleben 2007; Reilly 2012.

${ }^{21}$ Buckland et al. 2006.

${ }^{22}$ Tipping 1994; Sadler 1991.

${ }^{23}$ Bachhuber 2006.

${ }^{24}$ Buckland and Sadler 1990; Sadler 1999.

${ }^{25}$ Smith 1964.

${ }^{26}$ Hoare et al. 2002.

${ }^{27}$ Leslie 2013, 183.

${ }^{28}$ Lemdahl et al. 1995.

${ }^{29}$ Pals and Hakbijl 1992.

${ }^{30}$ Lemdahl et al. 1995

${ }^{31}$ Buckland 1991.

${ }^{32}$ Armitage et al. 1999.

${ }^{33}$ Koch 1989.

${ }^{34}$ Hinton 1945.

${ }^{35}$ Koch 1989.

${ }^{36}$ Skidmore 1985; Panagiotakopulu 2004.

${ }^{37}$ Rozkosny et al. 1997.

${ }^{38}$ Skidmore 1996; Panagiotakopulu unpublished.

${ }^{39}$ Robinson 2005.

${ }^{40}$ Andersson 1986.

${ }^{41}$ Hakbijl 1986; Hakbijl 1987.

${ }^{42}$ Pelekassis 1962.

${ }^{43}$ Callaghan 2002.

${ }^{44}$ Hakbijl and de Groot 1997.

${ }^{45}$ Dillon and Dillon 1972.

${ }^{46}$ Chu and Wang 1975.

${ }^{47}$ Hinton 1945.

${ }^{48}$ Kenward 1979.

${ }^{49}$ Kenward 1980.

${ }^{50}$ Kenward and Allison 1994.

${ }^{51}$ Reilly 2012.

${ }^{52}$ Hellqvist 1999.

${ }^{53}$ Reilly 2012.

${ }^{54}$ Thompson 1967.

${ }^{55} c f$. Kenward and Hall 2012

${ }^{56}$ Jones 2013.

${ }^{57}$ Kenward 1980; Kenward 1988.

${ }^{58}$ Buckland et al. 2006.

${ }^{59}$ Kenward 1988.

${ }^{60}$ Kenward 1980

${ }^{61}$ Kenward 1988.

${ }^{62}$ Buckland et al. 2006.

${ }^{63}$ Ibid.

${ }^{64}$ Panagiotakopulu and Buckland unpublished.

${ }^{65}$ Hall et al. 2000.

${ }^{66}$ Carrot et al. 1999; Carrot et al. 2001; Johnstone et al. 1999.

${ }^{67}$ Hall and Kenward 2004.

${ }^{68}$ Koch 1989.

${ }^{69}$ Kenward 1975; Kenward 1976; Buckland et al. 2008.

${ }^{70}$ Kenward and Allison 1994.

${ }^{71}$ Robertson et al. 1989.

${ }^{72}$ Smith 2004; Smith 2012.

${ }^{73}$ Smith 2012.

${ }^{74}$ Smith 2007.

${ }^{75}$ Gardiner and Mehler 2007.

${ }^{76}$ Vickers and Buckland 2013.

77 Amorosi et al. 1992.

${ }^{78}$ Fridriksson 1959; Fridriksson 1960; Guðmundsson et al. 2012. 
${ }^{79}$ Landin 1961.

${ }^{80}$ Sveinbjarnadóttir 2012.

${ }^{81}$ Buckland et al. 1992; Sveinbjarnardóttir et al. 2007.

82 Buckland et al. 2008.

${ }^{83}$ Buckland et al. 2012.

${ }^{84}$ Konráðsdóttir 2010.

${ }^{85}$ Carus-Wilson 1967.

${ }^{86}$ Buckland et al. 1991.

${ }^{87}$ Panagiotakopulu et al. in prep.

${ }^{88}$ Novgorod in the Baltic (Hellqvist 1999); Oslo, Gamlebyen (Kenward 1988); London, St John Jerusalem (Smith and Chandler 2004), and Hull, Blanket Row (Carrott et al. 2001) in the British Isles; Reykholt (Buckland et al. 2012) and Stóraborg (Panagiotakopulu et al. in prep.) in Iceland.

${ }^{89}$ Oksanen et al. 2008.

${ }^{90}$ Barnes and De Grave 2001.

${ }^{91}$ The Late Bronze age shipwreck of Uluburun (Bachhuber 2006); the Roman shipwreck near the Roman fort at Laurium (Pals and Hakbijl 1992); the thirteenth century wreck of a cog at Oskarshamn in the Baltic (Lehmdahl et al. 1995); sixteenth century wreck of Willem Barents' ship on Novaya Zemlya (Hakbijl and de Groot 1997); the eighteenth century East Indiaman wrecks, the Swedish Goteborg (Andersson 1986) and the wreck of Amsterdam at Bulverhythe, west of Hastings, in East Sussex (Hakbijl 1986; Hakbijl 1987).

${ }^{92}$ Novgorod (Hellqvist 1999, Reilly 2012); Oslo (Kenward 1980; Kenward 1988); Storvågan, Langenes on Langøya (Vollen and Været) (Buckland et al. 2006); Bergen and Ingøy (Panagiotakopulu and Buckland unpublished); Kings Lynn and Hull (Hall et al. 2000; Carrot et al. 1999; Carrot et al. 2001; Johnstone et al. 1999); York (Robertson et al. 1989); London (Smith 2004; Smith 2007; Smith 2012); Faroes: Toftanes (Vickers and Buckland 2013); Iceland: Bessastaðir (Amorosi et al. 1992), Reykholt (Buckland et al. 2008; Buckland 2012), Gásir (Konráðsdóttir 2010), Stóraborg (Panagiotakopulu et al. in prep.).

${ }^{93}$ Novgorod in the Baltic (Hellqvist 1999); Oslo, Gamlebyen (Kenward 1988) in Norway; London, St John Jerusalem (Smith and Chandler 2004), and Hull, Blanket Row (Carrott et al. 2001) in the British Isles, and Reykholt (Buckland et al. 2012) and Stóraborg (Panagiotakopulu et al. in prep.) in Iceland.

\section{References}

Alsleben, A. 2007. Food consumption in the Hanseatic towns of Germany, in, S. Karg (ed.), Medieval Food Traditions in Northern Europe, 13-37. Copenhagen: National Museum of Denmark.

Amorosi, T., Buckland, P. C., Edwards, K. J., Mainland, I., McGovern, T. H., Sadler, J. P. and Skidmore, P. 1998. They did not live by grass alone: the politics and palaeoecology of fodder on the North Atlantic islands. Environmental Archaeology 1, 41-54.

Amorosi, T., Buckland, P. C., Ólafsson, G., Sadler, J. P. and Skidmore, P. 1992. Site status and the palaeoecological record: a discussion of the results from Bessastaðir, Iceland, in C. D. Morris and D. J. Rackham (eds), Norse and Later Settlement and Subsistence in the North Atlantic, 169-192. Glasgow: University of Glasgow.
Andersson, G. 1986. Insekter från ostindiefararen Götheborg. Report 1986-12-14. Göteborg: Natural History Museum.

Armitage, D. M., Kelly, M. P., Amos, K., Schaanning, S. and Spagnoli, W. 1999. The white-marked spider beetle, Ptinus fur (L.) in stored grain - biology, seasonal occurrence and control using a surface insecticidal admixture, in J. Zuxun (ed.), Proceedings of the 7th International Working Conference on Stored-product Protection 1, 51-57. Chengdu: Sichuan Publishing House of Science and Technology.

Bachhuber, C. 2006. Aegean interest on the Uluburun Ship. American Journal of Archaeology 110, 345-363.

Bain, A. and King, G. 2011. Asylum for wayward immigrants: historic ports and colonial settlements in northeast North America. Journal of the North Atlantic, special volume 1, 109-124.

Banks J., 2011 [1896]. D. J. Hooker (ed.). Journal of the Right Hon. Sir Joseph Banks Bart., K.B., P.R.S.: During Captain Cook's First Voyage in H.M.S. Endeavour in 1768-71 to Terra Del Fuego, Otahite, New Zealand, Australia, the Dutch East Indies, Etc. Cambridge: Cambridge University Press.

Barnes, D. K. A. and De Grave, S. 2001. Ecological biogeography of southern polar encrusting faunas. Journal of Biogeography 28, 359-365.

Barrett, J., Hall, A., Johnstone, C., Kenward, H., O'Connor, T. and Ashby, S. 2007. Interpreting the plant and animal remains from Viking-age Kaupang, in D. Skre, Kaupang in Skiringssal, 1, 283-320. Aarhus: Aarhus University Press.

Buckland, P. C. 1991. Granaries, stores and insects. The archaeology of insect synanthropy, in D. Fournier and F. Sigaut (eds), La Preparation Alimentaire des Cereales, 69-81. Rixenart: PACT.

Buckland, P. I. and Buckland, P. C. 2006. Bugs Coleopteran Ecology Package. Versions: BugsCEP v7.63; Bugsdata v7.11; BugsMCR v2.02; BugStats v1.22. (Downloaded February 2015 www.bugscep.com).

Buckland, P. C., Dugmore, A. and Sadler, J. P. 1991. Faunal Change or taphonomic problem? A Comparison of modern and fossil insect faunas from south-east Iceland, in, J. K. Maizels and C. Caseldine (eds), Environmental Change in Iceland Past and Present, 127-146. Dordrecht: Kluwer.

Buckland, P. C. and Panagiotakopulu, E. 2008. A palaeoecologist's view of landnám. A case still not proven? in C. Paulsen and H. D. Michelsen (eds), Símunarbók. Heiðursrit til Símun V. Arge á 60 ára degnum, 31-41. Tórshavn: Faroe University Press.

Buckland, P. C. and Panagiotakopulu, E. 2010. Reflections on North Atlantic island biogeography: a Quaternary entomological view, in S.-A. Bengtson, P. Buckland, P. H. Enckell and A. M. Fosaa (eds), Dorete - Her Book: Being a Tribute to Dorete Bloch and to Faroese Nature (Annales Societatis Scientiarum Færoensis Supplementum 52), 187-215. Tórshavn: Faroe University Press.

Buckland, P. C., Panagiotakopulu, E. and Buckland, P. I. 2004. What's eating Halvdan the Black? Fossil insects in the study of a burial mound in its landscape context, in J.H. Larsen and P. Rolsen (eds), Halvdanshaugen - 
Arkeologi, historie og naturvitenskap, 353-376. Oslo: University of Oslo.

Buckland, P. C., Panagiotakopulu, E., Buckland, P. I., Perdikaris, S. and Skidmore, P. 2006. Insect faunas from medieval Langenes in Arctic Norway, in R. Engelmark and J. Linderholm (eds), Proceedings from the 8th Nordic Conference on the Application of Scientific Methods in Archaeology, Umeå 2001, 17-32. Umeå: University of Umeå.

Buckland, P. C., Panagiotakopulu, E. and Sveinbjarnardóttir, G. 2008. A failed invader in the North Atlantic: the case of Aglenus brunneus Gyll. (Col., Colydiidae), a blind, flightless beetle from Iceland. Biological Invasions 11, 1239-1245.

Buckland, P. C. and Sadler, J. 1989. A biogeography of the human flea, Pulex irritans L. (Siphonaptera: Pulicidae). Journal of Biogeography 16, 115-120.

Buckland, P. C. and Sadler, J. 1990. Ballast and building stone: a discussion, in D. Parsons (ed.), Stone Quarrying and Building in England AD 43-1525, 114-125. Chichester: Philimore.

Buckland, P. C., Sadler, J. P. and Sveinbjarnardóttir, G. 1992. Palaeoecological investigations at Reykholt, Western Iceland, in C. J. Morris and D. J. Rackham (eds), Norse and Later Settlement and Subsistence in the North Atlantic, 149-168. Glasgow: University of Glasgow,.

Buckland, P. C., Vickers, K., Panagiotakopulu, E., Sadler, J. P., Buckland, P. I. 2012. Insect remains, in G. Sveinbjarnardóttir, Reykholt. Archaeological Investigations at a High Status Farm in Western Iceland, 218-241. Reykjavík: Snorrastofa and National Museum of Iceland.

Callaghan, A. 2002. Spanish fly undone. Antenna 26, 164-167.

Carrott, J., Hall, A., Jaques, D., Kenward, H., Large, F. and Worthy, D. 1999. Evaluation of Biological Remains from Excavations at Blanket Row (Stakis Casino) (site code STK98) (Reports from the Environmental Archaeology Unit, York, 99/12). York: Environmental Archaeology Unit.

Carrott, J., Hall, A., Jaques, D., Johnstone, C., Kenward, H. and Rowland, S. 2001. Technical Report: Plant and Animal Remains from Excavations in Blanket Row, Kingston-upon-Hull (site codes BWH97-00) (Reports from the Environmental Archaeology Unit, York, 2001/12). York: Environmental Archaeology Unit.

Carus-Wilson, E. M. 1967. The Iceland venture, in E. M. Carus-Wilson, Medieval Merchant Venturers, 98-142. London: Methuen.

Chu, H. F. and Wang, L.-Y. 1975. Insect carcasses unearthed from Chinese antique tombs. Acta Entomologica Sinica 18, 333-337 (in Chinese).

Coope, G. R. and Osborne, P. J. 1968. Report on the Coleopterous fauna of the Roman well at Barnsley Park, Gloucestershire. Transactions of the Bristol and Gloucestershire Archaeological Society 86, 84-87.

Deforce, K., Allemeersch, L., Stieperaere, H. and Haneca, K. 2014. Tracking ancient ship routes through the analysis of caulking material from shipwrecks? The case study of two 14th century cogs from Doel (northern Belgium). Journal of Archaeological Science 43, 299-314.
Dillon, D. S. and Dillon, L. S. 1972. A Manual of Common Beetles of Eastern North America (2 vols). New York: Dover Publications.

Englert, A. 2015. Large Cargo Ships in Danish Waters 1000-1250: Evidence of Specialised Merchant Seafaring Prior to the Hanseatic Period (Ships and Boats of the North, 7). Roskilde: Viking Ship Museum.

Ewert, C. U. and Salzer, S. 2006. Bridging the gap: the Hanseatic merchants' variable strategies in heterogeneous mercantile environments (Working paper prepared for the XIVth International Economic History Congress (Helsinki): session 110, 1-16.

Fridriksson, S. 1959. Korn frá Gröf í Öræfum. Arbók hins Íslenzka Fornleifafélags, 88-91.

Fridriksson, S. 1960. Jurtaleifar frá Bergthórshvoli á soguöld. Arbók hins íslenzka Fornleifafélags, 64-75.

Gardiner, M. F. and Mehler, N. 2007. English and Hanseatic trading and fishing sites in medieval Iceland: report on initial fieldwork. Germania 85, 385-427.

Guðmundsson, G., Sveinbjarnardóttir, G. and Hillman, G. 2012. Charred remains of grains and seeds from the medieval high-status farm site of Reykholt in western Iceland. Environmental Archaeology 17(2), 111-117.

Hakbijl, T. 1986. Remains of insects, in J. H. G. Gawronski (ed.), Amsterdam Project. Annual Report of the VOC Ship 'Amsterdam' Foundation 1985, 72-73.

Hakbijl, T. 1987. Insect remains: unadulterated Cantharidum and tobacco from the West Indies, in J. H. G. Gawronski (ed.), Amsterdam Project. Annual Report of the VOC Ship 'Amsterdam' Foundation 1986, 93-94.

Hakbijl, T. and De Groot, M. 1997. Insect Remains from Willem Barents' 1596 Arctic exploration preserved in 'Het Behouden Huys', Novaya Zemlya - with notes on the medicinal use of Cantharides, in A. C. Ashworth, P. C. Buckland and J. P. Sadler (eds), Studies in Quaternary Entomology - An Inordinate Fondness for Insects, 129-134. Chichester: Wiley \& Sons.

Hall, A., Carrott, J., Jaques, J., Johnstone, C., Kenward, H., Large, F. and Usai, R. 2000. Technical report: Studies on Biological Remains and Sediments from Periods 1 and 2 at the Magistrates' Courts site, Kingston-upon-Hull (site codes: MCH94 and MCH99). (Reports from the Environmental Archaeology Unit, York 2000/25 and 2000/33). York: Environmental Archaeology Unit.

Hall, A. R. and Kenward, H. K. 2004. Setting people in their environment: plant and animal remains from Anglo-Scandinavian York, in R. A. Hall, D. W. Rollason, M. Blackburn, D. N. Parsons, G. Fellows Jensen, A. R. Hall, H. K. Kenward, T. P. O'Connor, D. Tweddle, A. J. Mainman, and N. S. H. Rogers, Aspects of AngloScandinavian York 8/4: 372-426. York: Council for British Archaeology for York Archaeological Trust.

Hellqvist, M. 1999. Urban and Rural Environments from Iron Age to Medieval time in Northern Europe. Evidence from Insect Remains from South-Eastern Sweden and Novgorod, Russia (Acta Universitatis Upsaliensis 430). Uppsala: Uppsala University.

Hinton, H. E. 1945. A Monograph of the Beetles Associated with Stored Products. London: British Museum.

Hoare, P. G., Vinx, R., Stevenson, C. R. and Ehlers, J. 2002. Re-used bedrock ballast in King's Lynn's 'Town Wall' and the Norfolk port's medieval trading links. Medieval Archaeology 46, 91-106. 
Johnstone, C., Large, F., Jaques, D., Hall, A., Worthy, D., Carrott, J. and Kenward, H. 1999. Assessment of Biological Remains from Blanket Row, Hull (sitecode: BWH98) (Reports from the Environmental Archaeology Unit, York, 99/1). York: Environmental Archaeology Unit.

Jones, R. E. 2013. Bread upon the Waters. The St. Petersburg Grain Trade and the Russian Economy, 1703-1811. Pittsburgh: University of Pittsburgh Press.

Kenward, H. K. 1975. The biological and archaeological implications of the beetle Aglenus brunneus (Gyllenhal) in ancient faunas. Journal of Archaeological Science 2, 63-69.

Kenward, H. K. 1976. Further archaeological records of Aglenus brunneus (Gyll.) in Britain and Ireland, including confirmation of its presence in the Roman period. Journal of Archaeological Science 3, 275-277.

Kenward, H. K. 1979. The insect death assemblages, in B. S. Ayres, Excavations at Chapel Lane Staithe, 1978. Hull Old Town Reports Series 3 (East Riding Archaeologist 5), 65-72. Hull: East Riding Archaeological Society.

Kenward, H. K. 1980. Insect remains, in E. Schia, Feltene 'Oslogate 3 og 7'. De Arkeologiske Utgravninger $i$ Gamlebyen, Oslo. Volume 2, 134-137. Oslo: Universitetetsforlaget.

Kenward, H. K. 1988. Insect remains, in K. Griffin, R. H. Okland, A. K. G. Jones, H. K. Kenward, R. W. Lie and E. Schia, Animal bones, moss, plant, insect and parasite remains, in E. Schia (ed.), De arkeologiske utgravninger $i$ Gamlebyen, Oslo, 5 (Mindets tomt - 'Sondre felt'. Animal Bones, Moss-, Plant-, Insect- and Parasite Remains) 115-140. Øvre Ervik: Alveheim and Eide. Kenward, H. K. 1990. The insect remains (1981), in M. R. McCarthy, A Roman, Anglian and Medieval Site at Blackfriars Street, Carlisle: Excavations 1977-9 (Cumberland and Westmorland Antiquarian and Archaeological Society Research Series 4), 317-318, fiche 3/1-3. Carlisle: Cumberland and Westmorland Antiquarian and Archaeological Society.

Kenward, H. K. and Allison, E. 1994. Rural origins of the urban insect fauna, in A. R. Hall and H. K. Kenward (eds), Urban-Rural Connexions: Perspectives from Environmental Archaeology, 55-78. Oxford: Oxbow.

Kenward, H. K. and Hall, A. 2012. Dung and stable manure on waterlogged archaeological occupation sites: some ruminations on the evidence from plant and invertebrate remains in R. Jones (ed.), Manure Matters. Historical, Archaeological and Ethnographic Perspectives, 79-95. Aldershot: Ashgate.

Koch, K. 1989. Die Käfer Mitteleuropas, Ökologie 2. Krefeld: Goecke and Evers.

Konráðsdóttir, H. 2010. Archaeoentomological work on samples from Gásir in Eyjafjörður, in O. Vésteinsson, S. Guðmundsdottir Beck, Q. Mould, H. Konráðsdóttir, S. C. Juel Hansen and H. M. Roberts, Gásir Post Excavation Reports 2, 51-72. Reykjavík: Fornleifastofnun Îslands.

Landin, B. O. 1961. Ecological Studies on Dung-Beetles (Opuscula Entomologica, suppl. 19). Lund: Berlingska Boktryckeriet.

Lemdahl, G., Aronsson, M. and Hedenäs, L. 1995. Insekter från ett medeltida handelfartyg. Entomologiske Tidskrift 116, 169-174.
Leslie, R. C. 2013. Old Sea Wings, Ways, and Words: In the Days of Oak and Hemp (first published 1890). London: Forgotten Books.

Lindroth, C. H. 1957. The Faunal Connections between Europe and North America. New York: John Wiley.

Lorentzen, B., Manning, S. W., Cvikel, D. and Kahanov, Y. 2014. High-precision dating the Akko 1 shipwreck, Israel: wiggle-matching the life and death of a ship into the historical record. Journal of Archaeological Science 41, 772-783.

Martin, C. J. M. 1986. Treasure of the Land of Darkness: The Fur Trade and its Significance for Medieval Russia. Cambridge: Cambridge University Press.

Mosley, H. 2009. An Environmental Archaeological Analysis of a Sediment Core taken from the Björkö Straight, Lake Mälaren, outside the Viking town of Birka (Miljöarkeologiska Laboratoriet Report 2010004). Umeå: Umeå University.

Oksanen, J., Blanchet, F. G., Kindt, R. et al. 2008. Vegan: Community Ecology Package. Ordination methods, diversity analysis and other functions for community and vegetation ecologists.<http://cran.r-project.org, http://vegan.r-forge.r-project.org/>

Pals, J. P. and Hakbijl, T. 1992. Weed and insect infestation of a grain cargo in a ship at the Roman fort of Laurium in Woerden (Province of Zuid-Holland). Review of Palaeobotany and Palynology 73, 287-300.

Panagiotakopulu, E. 2004. Dipterous remains and archaeological interpretation. Journal of Archaeological Science, 31, 1675-1684.

Panagiotakopulu, E. 2014. Hitchhiking across the North Atlantic - insect immigrants, origins, introductions and extinctions. Quaternary International 341, 59-68.

Panagiotakopulu, E. and Buckland, P. C. 2013. Late Holocene insect faunas from Tasiusaq, South West Greenland, Boreas 42(1), 160-172.

Pedersen, F. J. G. 2006. Trade and politics in the medieval Baltic: English merchants and England's relations to the Hanseatic League 1370-1437, in, J. Amelang and S. Beer (eds), Public Power in Europe: Studies in Historical Transformations, 161-181. Pisa: Edizione Plus.

Pelekassis, C. E. D. 1962. A catalogue of the more important insects and other animals harmful to the agricultural crops of Greece during the last thirty-year period. Annales de l'Institut Phytopathologique Benaki 5(1), 1-103.

Reilly, E. 2012. Fair and foul: analysis of sub-fossil insect remains from Troitsky XI-XIII, Novgorod (19962002), in M. Brisbane, N. Makarov and E. Nosov (eds), The Archaeology of Medieval Novgorod in its Wider Context: A Study of Centre/Periphery Relations, 265282. Oxford: Oxbow Books.

Robertson, A., Tomlinson, P. and Kenward, H. K. 1989. Plant and Insect Remains from Coffee Yard, York (1987.1). An Environmental Archive Report (Reports from the Environmental Archaeology Unit, York, 1989/12). York: Environmental Archaeology Unit.

Robinson, M. A. 2005. The insects, in J. Gardiner and M. J. Allen, Before the Mast: Life and Death aboard the Mary Rose, 615-617. Portsmouth: Mary Rose Trust.

Rozkosny, R., Gregor, F., and Pont, A. C. 1997. The European Fanniidae (Diptera) (Acta Scientiarum 
Naturalium Academiae Acientiarum Bohemicae Brno 31(2)). Brno: Institute of Landscape Ecology, Academy of Sciences of the Czech Republic.

Sadler, J. P. 1991. Beetles, boats and biogeography. Acta Archaeologica 61, 199-211.

Sadler, J. P. 1999. Biodiversity on oceanic islands: a palaeoecological assessment. Journal of Biogeography 26, 75-87.

Schildhauer, J. 1985. The Hanse: History and Culture (transl. K. Vanovitch). Leipzig: Edition Leipzig.

Schofield, J. E., Edwards, K. J. , Erlendsson, E. and Ledger, P. M. 2013. Palynology supports 'Old Norse' introductions to the flora of Greenland. Journal of Biogeography 40(6), 1119-1130.

Skidmore, P. 1985. The Biology of the Muscidae of the World (Series Entomologica 29). Dordrecht: W. Junk.

Skidmore, P. 1996. A Dipterological Perspective on the Holocene History of the North Atlantic Area. Unpublished PhD thesis, University of Sheffield.

Smith, D. 2004. Insect remains, in, M. Ciaraldi, R. Cuttler, L. Dingwall and C. Dyer, Medieval tanning and retting at Brewood, Staffordshire. Staffordshire Archaeological and Historical Society Transactions 40, 40-46.

Smith, D. N. 2007. The insect remains, in D. Seeley, C. Phillpotts and M. Samuel, Winchester Palace: Excavations at the Southwark Residence of the Bishops of Winchester (MoLAS monograph 31), 142-144. London: Museum of London Archaeology Service.

Smith, D. N. 2012. Insects in the City: An Archaeoentomological Perspective on London's Past (British Series 561). Oxford: British Archaeological Reports.

Smith, D. N. and Chandler, G. 2004. Insect remains, in
B. Sloane and G. Malcolm, Excavations at the Priory of the Order of the Hospital of St John of Jerusalem, Clarkenwell, London (MOLAS monograph 20), 389394. London: Museum of London.

Sveinbjarnardóttir, G. 2012. Reykholt. Archaeological Investigations at a High Status farm in Western Iceland. Reykjavik: Snorrastofa and National Museum of Iceland.

Sveinbjarnardóttir, G., Erlendsson, E., Vickers, K., McGovern, T. H., Milek, K. B., Edwards, K. J., Simpson, I. A., Cook, G. 2007. The palaeoecology of a high status Icelandic farm. Environmental Archaeology 12, 187-206.

Thompson, M. W. 1967. Novgorod the Great: Excavations at the Medieval City. London: Evelyn, Adams and Mackay.

Tipping, C. 1994. Cargo handling and the medieval cog. Mariner's Mirror 80, 3-15.

Toulmin Smith, L. (ed.) 1964. The Itinerary of John Leland in or about the years 1535-1543. London: George Bell and sons.

Vickers, K., Bending, J., Buckland, P. C., Edwards, K. J., Stumann Hansen, S., Cook, G. 2005. Toftanes: the palaeoecology of a Faroese Landnám farm. Human Ecology 33, 685-710.

Vickers, K. and Buckland, P. C. 2013. The Coleoptera remains from Toftanes, in S. Stumman Hansen, Toftanes. A Viking age farmstead in the Faroe Islands. Archaeology, environment and economy. Acta Archaeologica, 84, 157-174.

Wubs-Mrozewicz, J. and Jenks, S. (eds) 2013. The Hanse in Medieval and Early Modern Europe. Leiden: Brill. 